\title{
The Implications of Changing Maritime Security Geo- Strategic Landscape of Southeast Asia Towards Indonesia's “Jokowi” Contemporary Foreign Policy
}

\author{
Darwis Beddu ${ }^{1}$, Abdul Razaq Cangara ${ }^{2}$, Bama Andika Putra ${ }^{3}$ \\ \{dbundhy@yahoo.com ${ }^{1}$, acacangara@unhas.ac.id ${ }^{2}$, bama@unhas.ac.id ${ }^{3}$ \} \\ Department of International Relations, Faculty of Social and Political Sciences, Hasanuddin \\ University, \\ Jl. Perintis Kemerdekaan KM. 10, Makassar 90245, Indonesia. ${ }^{1,2,3}$
}

\begin{abstract}
This study intends to expose Indonesia's national interest and foreign policy response towards the waning power of the United States (US) and the rise of China's power and dominance in Southeast Asia. It then finds that Indonesia's core national interest is to defend its offshore territorial integrity bordering to South China Sea, potentially encroached by China. Also, the policy response has been about redefining its foreign policy, moving from Susilo Bambang Yudhoyono administration's focus on centralizing ASEAN to deal with conflictual dynamics US-China relations in Southeast Asia, towards establishing a more nationalistic foreign policy approach branded as Global Maritime Fulcrum, exposing a hedging strategy that combines balancing and engagement strategy towards China. Through balancing strategy, Indonesia still maintains defensive-careful behaviour towards China's assertiveness in the region. Meanwhile, through engagement strategy, Indonesia cooperates with China through its Belt and Road Initiative (BRI), expected to provide financial assistance for the realization of Global Maritime Fulcrum's infrastructure projects.
\end{abstract}

Keywords: Maritime Security, Indonesia's Foreign Policy, Southeast Asia, Jokowi, South China Sea.

\section{Introduction}

Southeast Asia always becomes the avenue for geostrategic competitions among the major powers. During the cold war, the competition was between the United States (US) and the Union of Soviet Socialist Republics (USSR), exposing a geostrategic competition in Southeast Asian region, competing for the ideological sphere of influence expansion. The US expanded the ideology of liberal capitalism, and meanwhile, USSR extended its communist ideology to the region. For the sake of it, both countries balanced its other by extending strategic alliance in the region, that caused several proxy wars, including Vietnam war, and Indonesia's assault in East Timor [1].

After the cold war ended in 1991 where the USSR had fallen apart and made the triumph of the US and liberal capitalism ideology, the US then turned as a superpower dominating world order. However, despite enjoying the preponderance of power and global domination, along with it, other major powers have begun to emerge, both in terms of economic and political power. One of them is China. It has been growing economically, politically, and militarily powerful since its economic opening in 1980s. To date, it has become the apparent rival of the US, competing for dominance in the Asia-Pacific, including the Southeast Asian region [2]. 
Both countries mostly have immense interests in Southeast Asia. The US, for instance, besides the need to assure its security alliance system in Southeast Asia, it also needs to assure and safeguards the freedom of commercial navigation in the South China Sea (SCS), in order to give security to its and trade counterpart's commercial ship doing export and import. To do so, it maintains its military presence in the region concurrently with ensuring the peaceful settlement of maritime disputes between China and other claimants in the SCS (including Southeast Asian claimant states: Indonesia, Malaysia, Brunei, Vietnam, and the Philippines) [3]. On the other hand, China's rising as a foremost economic power have been followed by the extended interest of becoming a regional hegemon. It has continued to enhance its strategic-military capabilities, aligning it with the expansion of its political-economic influence over Southeast Asian region, including to back up its assertive territorial claims in the SCS. Accordingly, as said by former Ambassador of US to China Robert Blackwill (2015) that China has an intention to erode the US influence in Asia. It is critical for China, since to become a regional hegemon, it must supersede the US dominance and tear apart its alliance system in the region [1], [4].

Having the above mentioned conflicting interests, they have brought both the US and China in a great maritime rivalry in Southeast Asia. It is apparent in their recent maritime geostrategic moves in it. The US per se, since Obama administration, has extended foreign policy of US pivot/rebalance in Asia in 2009 emphasizing the enhancement of military presence in Asia, including in Southeast Asia, such as adding more military personnel in Singapore and the Philippines, stationing four littoral combat ships in Singapore, and extending military cooperation with other Southeast Asian countries [5]. Balancing against the US, China consistently modernizes its military, increasing its military expenditure with ten times increase every year to support its interests. Even further, China has initiated an ambitious mega project of Belt and Road Initiative (BRI), including its subset of land reclamation in the SCS, emphasizing land and maritime infrastructure connectivity that will connect its economy with Asia and Europe. All these moves have recently incurred a new reality of changing dynamics of geostrategic maritime security in the Southeast Asian region. Nevertheless, these geostrategic maritime rivalries appear different from the previous rivalries of the US and USSR, where the geostrategic competition was for the sake of ideological expansion. Meanwhile, the US and China geostrategic "maritime" rivalries put them more onto geo-economic competition, aiming for ensuring the market for their exports and other economic benefits [6],[7],[8].

For Southeast Asian countries, there is a necessity to recalibrate their foreign policy amid the rivalries between the US and China. This situation is also not exclusive to Indonesia. As a leading country both regionally of Southeast Asia and institutionally of ASEAN, Indonesia's international behavior, for sure, will also determine the geostrategic power play in it. Therefore, this research is interested in investigating Indonesia's foreign policy under Joko Widodo first term presidentship amidst the changing dynamics of maritime security geostrategic landscape, caused by US-China rivalries in the region [7], [9]. Therefore, this research raises a question to answer, encompassing "how does Indonesia respond towards such changing maritime security geostrategic landscape"?

\section{Research Method}

The type of research used is descriptive qualitative. This method explains Indonesia's foreign policy response under Joko Widodo administration towards the changing maritime security geo-strategic landscape of Southeast Asia. 
The data collection technique used to acquire the necessary data for this research is literature review. The method covers the examination of various literatures related to the problems studied, encompassing books, journals, documents, papers, reports, magazines, newspapers, and articles related to research problems. Also, the data analysis technique used the by authors is qualitative analysis techniques[10]. The writing method used is a deductive method, by describing the problem in general first, then narrowing its scope of discussion specifically, and drawing specific conclusions in analyzing the data afterwards[11].

\section{Result and Discussion}

\subsection{The Dynamics of Southeast Asia Maritime Geostrategy: The Declining Trend of the US Military Presence in Asia, Undelivered Promise of US Rebalance in Asia, and the Rise of China}

Mentioned briefly in the introduction that the changing dynamics of Southeast Asia maritime geostrategy is the consequence of geostrategic power balancing between the US and China in the region. The particular change is about a gradual shift of power domination from the US towards China. Accordingly, this research argues that China almost achieves the geostrategic power parity towards the US in Southeast Asia. The main causes are about undelivered promise of the US rebalance strategy in Asia, concurrently with China's military and maritime geostrategic power continue to rise, and undeterrable by the US military rebalance strategy. The details will be further briefly discussed in the next section $[12,13]$.

\subsubsection{Undelivered Promise of US Rebalance in Asia}

In 2009, the Obama administration issue signature foreign policy of US Pivot/Rebalance to Asia, where one of its aspects is strategic-military rebalance. In it, President Obama envisioned that the US would shift $60 \%$ of its strategic-military assets in Asia, aiming to play a more significant role in shaping its future direction. It admitted that the previous strategic focus was given to much towards enduring wars in the Middle East, thus leaving benign neglect towards the Asian region. It has given rooms for regional power such as China to rise and potentially replace US dominance in Asia. Meanwhile, President Obama has recognized that the center of world's economic gravity to date is Asia, including Southeast Asian. At the same time, it also encounters assertive belligerent behavior of China in East and Southeast Asia, in particular to its claims in the territorial conflict in SCS, that threatens the US interest in the region[3-5].

In terms of interest, the fact shows that since 2000, Asia is the foremost source of US imports and the second-largest market for its export. Accordingly, these trade flows through the strategic Sea-Lane of Communication (SLOC) in Asia, such as Malacca strait and SCS, which substantially intersect with Southeast Asian countries maritime boundaries. At these junctures, the US has the interest to assure the security of SLOC of Southeast Asia. Any disruptions towards it for sure would impede the US as well as global trade. Through US strategic-military pivot/rebalance to Asia, it emphasized reinforcing its military presence in the region as a response and domestication of China's assertive and belligerent behavior in the region, that might disrupt the freedom of commercial navigation along Southeast Asia's SLOC. Accordingly, the policy rhetoric of US strategic-military rebalance in Asia substantiated the strengthening of military capacity of its formal alliances and strategic partners in the Asia 
Pacific such as Australia, Japan, South Korea, Philippines, and Singapore, through extending the number of troops deployment, naval deployment, as well as constructing new dimensions of military cooperation with Indonesia, Singapore, Thailand, and Vietnam . In details, this was done by deploying up to 2.500 rotational troops at Darwin, Australia, 40.000 troops in Japan, 16.000 floating troops near Japan, 28.500 troops in South Korea, 500 rotational troops in Philippines, 4.500 troops in Guam. Additionally, the US also stationed four its littoral combat ships in Singapore. Moreover, The US also notified international community towards its plan with Australia to allow the greater access of the US Navy and the US Airforce towards the Australian naval base at Perth and Royal Australian Air Force facilities at any bases respectively. These increasing military activities were involving 1.850 aircraft, six aircraft carriers, 143 navy ships, six landing ship docks, four amphibious transport docks, 11 cruisers, 13 frigates, 31 destroyers, and 36 submarines[1,5].

Even though the US rebalance in Asia rhetoric is powerful, its implementation afterward did not run as planned. The US's 15 years of Middle East war (Afghanistan \& Iraq War, Libya \& Syrian war, and war against ISIS) following military budget cuts by the congress impose hardships towards the US rebalance in Asia's realization. Data shows that its military budget allocation was less than $\$ 10-\$ 15$ billion out of the approximately $\$ 600$ billion annual defense budget. This budget cut impeded a wider distribution of forces, a required long-term procurement of military apparatus (investment in navy, and military system to defend at-risk land and sea-based target). Accordingly, there was not enough dollar to develop or acquire new systems, let alone to significantly increase force structure in the Asia-Pacific region. Also, the scale of US pivot/rebalance to Asia was modest comparing it with US strategic-military balancing towards the USSR in the period of Cold War. As stated by US Secretary of Defense Leon Panetta that by $2020,60 \%$ of US naval assets will be in the Pacific and just $40 \%$ in the Atlantic. Nevertheless, most of those naval assets based in the US, not in Asia, meaning that those ships could be deployed to the other regions aside of Asia. Furthermore, its overseas basing arrangement was also limited and modest. It was evident in the deployment of just two (from four planned) littoral combat ships to Singapore[12, 14]. Overall, there was an immense gap between the policy rhetoric and implementation of the US rebalance strategy in Asia.

\subsubsection{The Rise of Assertive China}

The US rhetoric of pivot to Asia has just basically induced security dilemma in Asia. It provoked and generated a sense of strategic encirclement in the China side. It viewed the policy as orienting to contain its rise, thus posing inherent threats toward China's territorial integrity. It mostly had terrible experience regarding strategic encirclement, as it was the cause of century of humiliation that it had ever experienced. This perceived strategic encirclement includes US military bases surrounding China's outer edges, the US joint military exercises, and extended deployment of the US advanced theater missile defense[12, 15]. To respond and balance against the US, China extended:

a) Increasing annual military expenditures

b) PLA Reformation

a. Deep reforms and massive reorganization of PLA

b. Military \& Nuclear Modernization

i. Rebalancing China's military - Compete with Air-Sea Battle Concept of US Pivot to Asia 
1. Army smaller but a nimbler, more balance force with expeditionary capabilities

2. Preferential treatment to the navy \& air force
ii. Upgrading nuclear forces
iii. Developing a new ballistic missile submarine
iv. Counter-space weapons
v. Militarization of South China Sea: Spratly and Paracel (Woody) Island
vi. The use of Chinese maritime militias

Recognizing China's responses above, it could be said that the US pivot/rebalance to Asia has just provoked China's to be more aggressive and resistance towards the US. Instead of domesticating China, it appears as unable to deter and moderate China's assertive behavior. This situation is in line with former US Ambassador to China Robert Blackwill (2015) that China seeks to attain these goals: a) superseding the US predominance and further altering the balance of power in Asia; b) weakening the US's alliance system in Asia by diminishing the confidence of Asian nations in US leadership, reliability, credibility, and staying power; c) capitalising its giant economic power to influence Asian nations to always accommodate the geopolitical policy preferences of China; d) improving China's military capability to reinforce deterrence against the US; and e) spreading hesitation on the US economic model. Fundamentally, all of these goals are not just illusions. They are currently being materialised. For instance, China has pushed its new economic initiatives of Belt and Road Initiatives (BRI) and the Asian Infrastructure Investment Bank (AIIB) to promote broader economic integration in Asia-Pacific. Currently, China has embraced around 60 countries to advance these agendas jointly[1], [7], [16].

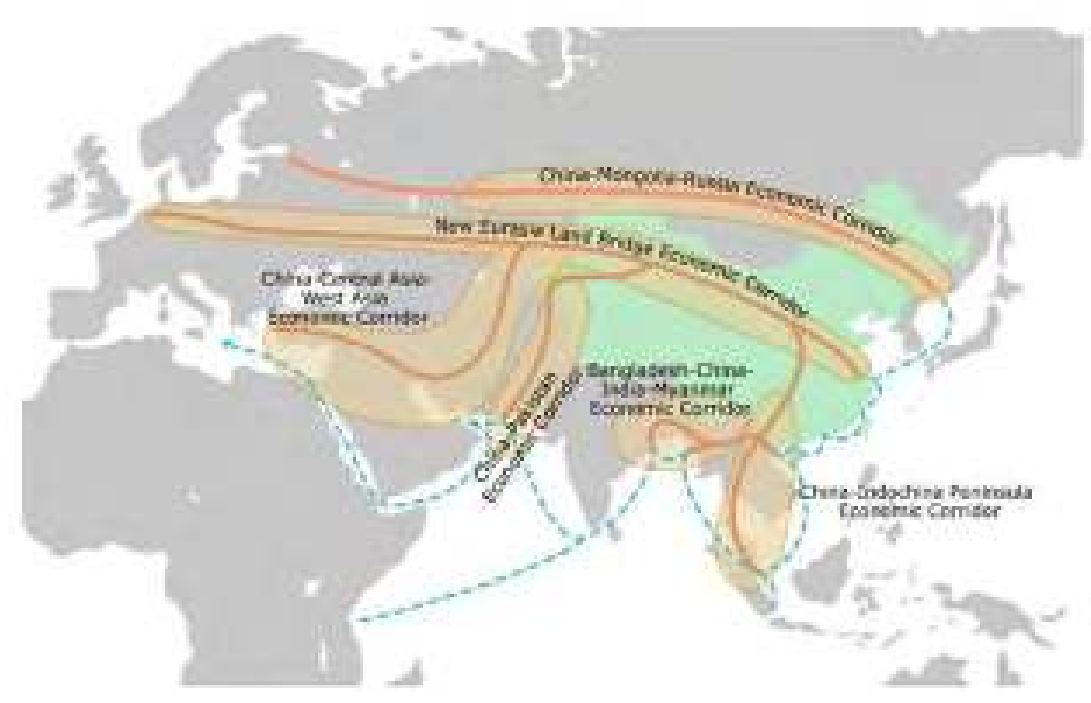

Fig 1. The BRI's Six Economic Corridor

Through BRI, China wants to promote global trade by enhancing infrastructure and economic connectivity among Eurasian countries. To realize it, China immensely promotes 
infrastructure development, including railways and highways stretching from Europe to Asia, aiming to improve trade and logistics networks for countries participating in it. The realization of BRI then would enmesh the market of 4.4 billion people and might contribute more than USD 21 trillion to the world's GDP. Additionally, the existence of AIIB would help to fund BRI infrastructure development projects. Overall, China expects that all those projects would realize its ambition to supersede US dominance in Asia [7], [17].

\subsection{The Changing Maritime Geostrategic Landscape of Southeast Asia: Impact towards Indonesia's Foreign Policy}

The changing dynamics of maritime geostrategic landscape in Southeast Asia, as the consequence of US-China geostrategic rivalries, has brought immense implications towards Indonesia's foreign policy. During the Susilo Bambang Yudhoyono (SBY) administration, Indonesia put leadership and emphasize as an honest broker, by using Association of Southeast Asian Nations (ASEAN) as the backbone of neutralizing any tensions occurring in the SCS between the US, China, and other ASEAN's claimant states. However, Jokowi administration undertook different response from its predecessor. Indonesia's foreign policy, under Jokowi's presidentship, has been more pragmatic and nationalistic and seen ASEAN as not the fundamental of its foreign policy[16].

\subsubsection{Indonesia's “Jokowi” Contemporary Foreign Policy: The Global Maritime Fulcrum.}

Responding to the geostrategic dynamics in Southeast Asia, President Joko Widodo envisions Indonesia to take advantages from such changing regional constellation. He decides to advance Indonesia as a maritime power that has a central position in the dynamics of the international relations in Asia-Pacific. For this sake, in East Asia Summit 2014 in Myanmar, he announced Indonesia's foreign policy agenda of Global Maritime Fulcrum, envisioning Indonesia not just as an archipelagic but also a maritime country. Through Global Maritime Fulcrum foreign policy doctrine, he wants to make Indonesia as a great and prosper maritime power by reinventing its maritime identity, safeguarding its maritime interest, security, and territorial integrity, empowering maritime potentiality (including shipping and fishing industries), enhancing maritime infrastructure connectivity, and facility to realize balance economic distribution across Indonesia [4], [7].

The most important thing about Global Maritime Fulcrum then is about its inward-looking pragmatic approach, where any kinds of Indonesia's international endeavors are directed to secure its national interests. At this point, this research would analyze the Global Maritime Fulcrum implementation in the perspective of hedging strategy. The hedging strategy per se is a combination of balancing (competition) and engagement (cooperation) in dealing with other countries. Accordingly, this research further argues that there is a dichotomy of interest that Jokowi administration pursues in the Global Maritime Fulcrum doctrines, encompassing security, and economic interests. In the context of achieving security interests, Indonesia still carefully behaves and even strategically balances against China. In this case, Indonesia still needs the US military presence as a strategic partner to tame China's assertive maritime behavior in the region. It is critical, as the element of Global Maritime Fulcrum is about ensuring maritime territorial integrity and security. To this regard, Indonesia realizes that the territorial conflict in the SCS potentially increases the insecurity of the region bordering to Indonesia. It is evident in the potential China's encroachment and claims over Natuna sea that directly borders 
with SCS. The upmost concern to protect Natuna sea is on its richness over natural gas reserves, which are vital towards Indonesia's energy security [7], [13], [18], [19].

In the context of achieving economic interest, this research argues that Indonesia engages with China cooperatively, as it provides financial assistance opportunity for Indonesia to succeed its Global Maritime Fulcrum ambition to realize maritime infrastructure development and connectivity that would reinforce its position in the global market. Indonesia recognizes its identity as the largest archipelagic states, strategically linking the Indian and Pacific Ocean. Therefore, there is an urgent necessity to use and elevate this identity for the advantages of Indonesia. Still, the lack of quality infrastructure poses stumbling blocks to elevate the value of such identity. The main problem that the Indonesian government faces is a budget constraint to finance and fund the infrastructure projects. In the National Mid-Term Development Plan (RPJMN) 2015-2019, it needs at least USD 460 billion or around IDR 5.500 trillion during 2015-2019 to realize its infrastructure development objectives. Therefore, China's BRI is expected to help Indonesia out from this budget constraint, by investing and giving loan to Indonesian government so that it could realize infrastructure objectives of Global Maritime Fulcrum [3], [7], [17].

\section{Conclusion}

As a conclusion, the changing dynamics of the maritime geostrategic landscape of Southeast Asian region following the declining trend of US military presence and the rise of assertive China do not dictate Indonesia's foreign policy conduct. Observing the regional dynamics, Indonesia autonomously decided to launch Global Maritime Fulcrum as its foreign policy doctrines to adapt with such changing regional dynamics. In its essence, this policy is more inward-looking and pragmatic as it prioritizes the achievement of Indonesia's national interest, both in security and economic realms. With this emphasis, Indonesia's government cultivate hedging strategy, exposing balancing and engagement strategy to deal with China's international behavior in the region.

\section{Reference}

[1] Blackwill RD, Tellis AJ. Revising U.S.: Grand Strategy Toward China. Washington, DC, http://www.cfr.org/china/revising-us-grand-strategy-toward-china/p36371 (2015).

[2] Mearsheimer JJ.: China's Unpeaceful Rise. Curr Hist; 105: 160-162 (2006)

[3] Art RJ. The United States and the Rise of China: Implications for the Long Haul. Polit Sci Q; 25: 359-391 (2010)

[4] Xu B.: South China Sea Tensions. Council on Foreign Relations, http://www.cfr.org/china/southchina-sea-tensions/p29790 (2014, accessed 14 May 2014).

[5] Manyin M, Daggett S, Dolven B, et al.: Pivot to the Pacific? The Obama Admnistration's "Rebalancing" Toward Asia. Washington DC, https://www.fas.org/sgp/crs/natsec/R42448.pdf (2012).

[6] Wong, E., and Buckley C.: China's Military Budget Increasing 10\% for 2015, Official Says. New York T, 2015, http://www.nytimes.com/2015/03/05/world/asia/chinas-military-budget-increasing10-for-2015-official-says.html? rr=2 (2015).

[7] Damuri YR, Perkasa VP, Atje $\overline{\mathrm{R}}$, et al.: Perceptions and Readiness of Indonesia Towards the Belt and Road Initiative. Jakarta (2019)

[8] Wang D, Yin C.: Mainland China Debates U.S. Pivot/Rebalancing to Asia. Issues Stud 2014; 50: 
57-101 (2014)

[9] Walt SM.: Where Do We Draw the Line on Balancing China. Foreign Policy, 2015, http://foreignpolicy.com/2015/04/27/where-do-we-draw-the-line-on-balancing-china/ (2015).

[10] Creswell JW.: Research Design: Qualitative, Quantitative and Mixed Methods Approaches. 3rd ed. California: Sage Publication (2009)

[11] Denzin NK.: Handbook of qualitative research. Yogyakarta: Pustaka Pelajar (2009)

[12] Lai D, Stevens C.: Fixing the U.S. Rebalance to the Asia-Pacific. The Diplomat, 2014, $\mathrm{http}: / /$ thediplomat.com/2014/06/fixing-the-u-s-rebalance-to-the-asia-pacific/ (2014).

[13] Krepinevich, Jr A. How to Deter China: The Case for Archipelagic Defense. Foreign Aff 94: 78-86 (2009)

[14] Lynch D.: China Challenges Obama's Asia Pivot with Rapid Military Buildup. Bloomberg.com, http://www.bloomberg.com/news/articles/2014-04-23/china-defies-obama-s-slow-asia-pivot-withrapid-military-buildup (2014, accessed 12 September 2015).

[15] Browne BR, Jiang S, Gafas M.: US Navy warship challenges Chinese claims in the South China Sea. 2019; 1-3 (2019)

[16] Laksmana EA, Gindarsih I, Mantong AW.: Menerjemahkan Visi Poros Maritim Global kedalam Kerangka Diplomasi Pertahanan Maritim dalam Kebijakan Luar Negeri Indonesia di Era Jokowi. Jakarta,

https://www.csis.or.id/uploaded_file/publications/menerjemahkan_visi_poros_maritim_global_ke_ dalam_kerangka_diplomasi_pertahanan_maritim_dalam_kebijakan_luar_negeri_indonesia_di_era_ jokowi.pdf (2018).

[17] Ye M.: China's Silk Road Strategy: Xi Jinping's real answer to the Trans-Pacific Partnership. Foreign Policy, 2014, http://foreignpolicy.com/2014/11/10/chinas-silk-road-strategy/ (2014, accessed 2 November 2015).

[18] Detik.com.: Tiba di Natuna, Jokowi gelar rapat di KRI yang tembak kapal Cina. Detik.com, June (2016)

[19] Holmes J.: The Two Words That Explain China's Assertive Naval Strategy. Foreign Policy, 2015, http://foreignpolicy.com/2015/06/03/the-two-words-that-explain-chinas-naval-strategy-activedefense/ (2015). 